possible should be done to encourage in the pro. fession a continuous supply of men of that type. There are, in the profession, young men, many as yet little known, who have courage and initiative to come forward with new work, to read papers, and to make useful and sensible contributions to discussions. To be able to express themselves clearly and with assurance on matters on which they can claim to know something is a valuable asset in itself. $\mathrm{He}$ would suggest to the younger members that much could be done to acquire this ability by good reading, by cultivating the habit of mixing with men of other professions, and by taking an active interest, not only in the proceedings of the societies devoted to their science, but also in the world of affairs generally. The supply of men and women for administrative posts is a difficult problem. There is another side of the question, however, namely, that in attaining an administrative post with the responsibility that it entails, there is a danger of the chemist losing touch with his science, so that it becomes more and more difficult for him to encourage the workers in the laboratories. Dr. Pickard was re-elected president of the Institute for the ensuing year.

\section{Smoke Reducing Grates for Domestic Use}

IN NATURE of January 23, an article on the prevention of smoke and dust emission referred to the difficulty experienced in burning raw coal smokelessly in the conventional open grate, and stated that investigations are now in progress having as their object the removal of this source of atmospheric pollution. The fundamental cause of smoke production from a domestic fire is the low temperature obtaining in the space above the fuel bed, combined with the cooling of the hot products of combustion by excess air entering the face of the grate. This normally gives rise to partial combustion of the hydrocarbon distillation products and the evolution of materials rich in carbon, but at certain periods, notably on kindling and on refuelling, the tarry matter may pass into the atmosphere unchanged.

To overcome these defects, a number of grate designs have been advanced, and the more important may be divided roughly into four classes. In the first, preheated air is supplied to the space above the fuel, increasing the temperature and promoting the early combustion of the volatile matter. This method can only be partially successful, as both the air supply and its temperature will be lowest just before adding a fresh charge. The second class, which is used in many multiple purpose grates, employs a draught which carries the distillates downwards through the hot fuel, giving conditions more suitable for their combustion. In these two, the smoke from the ignition charge is little altered. Gas is used in the third class as an auxiliary to burn the smoke. A novel example of this type was demonatrated recently by the Coal Utilisation Council, British Industries House, Marble Arch, London, W.1. The final class consists of more complicated devices in which the heat from the fire partially carbonizes raw coal contained in a suitable receptacle, the distillation products passing through the burning fuel where they are consumed. Dr. Arnot's smoke consuming grate (1855) was the forerunner of this type, but more recently a gravity feed from a hopper behind the fireback brings it more into line with modern ideas.

\section{Control of the Grid System in Great Britain}

IN a paper, read to the Institution of Electrical Engineers on February 10, Mr. J. D. Peattie describes the control rooms provided by the Central Electricity Board for controlling the generating stations supplying electricity to the grid and for supervising the operation of the transmission lines. The whole of Great Britain with the exception of northern Scotland is now divided into nine schemes. These are grouped into seven systems which are controlled from seven centres, at Glasgow, Newcastle, Leeds, Manchester, Birmingham, Bristol and London respectively. For short distances, continuous metallic circuits are provided, but for longer distances the Post Office channels pass through repeating stations and alternating current signals only are transmitted. The telephones and automatic indicating apparatus are always combined in one equipment suitable for use in conjunction with the channels hired from the Post Office. The vital line of communication is that connecting the control engineer on duty and the operator at the distant station.

IN general, the control engineer has access to, and a prior claim from his desk on, the outgoing channels. By means of automatic indicating apparatus he knows the position of the circuit breakers, the routine instruction signals and the readings of the load. In most cases the transmitting and receiving equipment for the signals are developments of apparatus used in automatic telephony. As a check on the frequency and time control carried out by the operators at the generating stations, meters connected to the local supply are installed in each control room. Differential dials are provided showing the difference between the time given by a high-grade standard clock and the system time given by the synchronous motor clocks. The standard clock is checked daily against the Greenwich radio time signal. Differential dials are also provided showing the difference between the time given by the standard clock and the system time given by a synchronous motor clock.

\section{Recent Acquisitions at the Natural History Museum}

Among recent acquisitions in the Department of Zoology are the mounted head of a Mexican bighorn sheep presented by Mr. John Lawson, the head of a Newfoundland caribou presented by Mr. W. Lawson, and the head of a woodland caribou presented by Captain D. A. Lawson. The study collection has been enriched by an Argali sheep skin from Samarkand, the gift of $\mathrm{Mr}$. Douglas Carruthers, and a tiger skin and skull from Perak presented by the Zoological Society. Miss Emma Hutchinson of Grantfield, Leominster, Herefordshire, has presented to the Museum the collection, contained in four cabinets, of British Lepidoptera made at Leominster by her 